\section{PREDICTIVE RISK MODELS FOR TRANSCATHETER PROCEDURES: HOW SHOULD THEY BE CREATED?}

\section{To the Editor:}

For decades, the scientific community has tried to create a reliable risk model to predict mortality after cardiac surgery. In 1995, the European system for cardiac operative risk evaluation (EuroSCORE) ${ }^{1}$ was published as a risk model derived from data collected from 14,799 consecutive patients in 100 European centers. Despite its thoroughness, EuroSCORE I overpredicted the mortality risk of the patients undergoing cardiac surgery. One reason might have been that it was created using data from a highly heterogeneous patient group. Thus, because most of the group had coronary artery disease, EuroSCORE I was more predictive for patients undergoing coronary artery surgery. Moreover, the model accounted for only the most common and prevalent risk factors for 30-day mortality but not rare ones. Finally, surgical techniques and postoperative patient management are constantly changing and improving over time, making EuroSCORE I a redundant model.

In an immense effort to overcome these limitations, in 2012, a new version was published. This system, EuroSCORE II, $^{2}$ was created from the results of $>22,000$ patients who had undergone cardiac surgery in 2010 at 154 hospital centers. However, the external validation of the

\footnotetext{
The Editor welcomes submissions for possible publication in the Letters to the Editor section that consist of commentary on an article published in the Journal or other relevant issues. Authors should: - Include no more than 500 words of text, three authors, and five references. - Type with double-spacing. - See http://jtcs.ctsnetjournals.org/misc/ifora.shtml for detailed submission instructions. - Submit the letter electronically via jtcvs.editorialmanager.com. Letters commenting on an article published in the JTCVS will be considered if they are received within 6 weeks of the time the article was published. Authors of the article being commented on will be given an opportunity of offer a timely response ( 2 weeks) to the letter. Authors of letters will be notified that the letter has been received. Unpublished letters cannot be returned.
}

model failed again when it was assessed by independent researchers. ${ }^{3}$ Some of the reasons have been identified. The EuroSCORE II included variables that were not significantly associated with mortality, had removed one of the major predictors of EuroSCORE I (postinfarction ventricular septal rupture) because of its low incidence, and, finally, did not analyze other variables that could have had a major weight in an updated score. ${ }^{3}$

Transcatheter aortic valve implantation has come to stay and, despite its recent appearance, has already been shown to be an acceptable alternative for high-risk patients. However, a reliable predictive risk score for these recent techniques has not yet been developed; therefore, previous predictive models for cardiac surgery have been used. Nevertheless, the results have not been satisfactory. The inclusion of irrelevant variables for percutaneous procedures (eg, previous cardiac surgery) and the absence of common and relevant parameters normally associated with these interventions (eg, liver dysfunction or a porcelain aorta) have very likely weakened these predictive models. The report recently published by Beohar and colleagues ${ }^{4}$ serves to confirm the conclusions of previous studies and highlights the need for a specific model for transcatheter procedures.

Therefore, for decades we have been searching for a perfect and reliable predictive risk model for traditional cardiac surgery, and we have not yet achieved it. It is likely that great variability exists in the results of conventional surgery between surgeons and centers ${ }^{5}$ that could make it difficult to determine the accuracy of any model. From our experience in traditional surgery, the creation of a reliable model for transcatheter techniques must use recent data from a homogeneous sample formed by a large number of patients from different centers and should include the most clinically relevant variables for this procedure. However, we believe this titanic undertaking will only be achieved if the outcomes among different centers are more homogeneous than those observed with traditional surgery.

Daniel Hernández-Vaquero, $M D, P h D$ Rocío Díaz, $M D^{a}$

César Morís, $M D, P h D^{b}$

${ }^{a}$ Department of Cardiac Surgery

Heart Area

Central University Hospital of

Asturias

Asturias, Spain

${ }^{b}$ Department of Cardiology

Heart Area

Central University Hospital of

Asturias

Asturias, Spain

Disclosures: Dr Cesar Morís is

Proctor for CoreValve (Medtronic, Minneapolis, Minn).

\section{References}

1. Nashef SA, Roques F, Michel P, Gauducheau E Lemeshow S, Salamon R. European system for cardiac operative risk evaluation (EuroSCORE). Eur J Cardiothorac Surg. 1999;16:9-13.

2. Nashef SA, Roques F, Sharples LD, Nilsson J, Smith C, Goldstone AR, et al. EuroSCORE II Eur J Cardiothorac Surg. 2012;41:734-44

3. Barili F, Pacini D, Capo A, Rasovic O, Grossi C Alamanni F, et al. Does EuroSCORE II perform better than its original versions? A multicentre validation study. Eur Heart J. 2013; 34:22-9.

4. Beohar N, Whisenant B, Kirtane AJ, Leon MB, Tuzcu M, Makkar R, et al. The relative performance characteristics of the logistic EuroSCORE and the Society of Thoracic Surgery score in the PARTNER trial. $J$ Thorac Cardiovasc Surg. May 10, 2014 [Epub ahead of print]

5. Gonzalez AA, Dimick JB, Birkmeyer JD, Ghaferi AA. Understanding the volume-outcome effect in cardiovascular surgery: the role of failure to rescue. JAMA Surg. 2014;149:119-23.

http://dx.doi.org/10.1016/ j.jtcvs.2014.05.012

\section{Reply to the Editor:}

We appreciate the insights provided by $\mathrm{Dr}$ Hernandez-Vaquero and colleagues regarding our report titled "The relative performance characteristics of the Logistic EuroSCORE and the Society of Thoracic Surgeons 
score in the PARTNER Trial." They pointed to the limited utility of the EuroSCORE $\mathrm{I}^{2}$ and newer EuroSCORE $\mathrm{II}^{3}$ algorithms to predict the outcomes of patients undergoing cardiac surgery and attributed this limited utility to heterogeneous patients, evolving surgical techniques and postoperative care, and outcome variability among surgeons and institutions. ${ }^{4}$ Although our report pointed to the limitations of the current algorithms when applied to a transcatheter aortic valve replacement (TAVR) population, we did not specifically address how to create new TAVR-specific algorithms. We agree with Dr Hernandez-Vaquero that developing TAVR-specific scores would be a most challenging but important task and that useful TAVR-specific scores will require a large cohort of patients from different centers and must include the most clinically relevant variables associated with TAVR outcomes. TAVR-specific risk scores are being developed, and we look forward to seeing their performance, especially as TAVR moves increasingly from randomized trials to real world applications.

\section{Nirat Beohar, MD \\ Division of Cardiology Columbia University \\ Miami Beach, Fla}

\section{References}

1. Beohar N, Whisenant B, Kirtane AJ, Leon MB, Tuzcu M, Makkar R, et al. The relative performance characteristics of the logistic European System for Cardiac Operative Risk Evaluation Score and the Society of Thoracic Surgeons score in the Placement of Aortic Transcatheter Valves trial J Thorac Cardiovasc Surg. April 13, 2014 [Epub ahead of print]

2. Nashef SA, Roques F, Michel P, Gauducheau E, Lemeshow S, Salamon R. European system for cardiac operative risk evaluation (EuroSCORE). Eur J Cardiothorac Surg. 1999;16:9-13.

3. Nashef SA, Roques F, Sharples LD, Nilsson J, Smith C, Goldstone AR, et al. EuroSCORE II. Eur J Cardiothorac Surg. 2012;41:734-44.

4. Barili F, Pacini D, Capo A, Rasovic O, Grossi C, Alamanni F, et al. Does EuroSCORE II perform better than its original versions? A multicenter validation study. Eur Heart J. 2013; $34: 22-9$

\section{http://dx.doi.org/10.1016/} j.jtcvs.2014.05.057

\section{USE OF STEREOTACTIC BODY RADIATION THERAPY WITH SALVAGE SURGERY TO IMPROVE OUTCOMES FOR EARLY STAGE NON-SMALL CELL LUNG CANCER \\ To the Editor:}

The role of stereotactic body radiation therapy (SBRT) and its integration into the treatment of early stage non-small cell lung cancer continues to evolve. The recent propensity-matched analysis by Crabtree and colleagues ${ }^{1}$ provides insights into how to combine SBRT with surgery to improve non-small cell lung cancer outcomes.

Crabtree and colleagues ${ }^{1}$ found that regional and distant recurrences were no different after SBRT or surgery throughout follow-up and that local recurrence alone caused the inferior disease-free survival seen with SBRT. This suggests that a strategy of using SBRT with prompt surgical salvage for suspected local recurrence may present the same probability of cure as surgery alone. With only $11 \%$ of patients having local recurrence after SBRT, the vast majority of SBRT-treated patients would not only achieve cure but also do so with lung preservation. SBRT with surgical salvage would immediately reduce operative mortality in absolute terms. A recent news release from the American Association for Thoracic Surgery found operative mortality is higher than appreciated, with a risk that persists for at least 90 days and from causes that are as yet unclear. ${ }^{2}$ Contemporary reports suggest that 30- and 90-day mortalities range between $1 \%$ and $5 \%$ and between $3 \%$ and $10 \%$, respectively. ${ }^{3}$ With SBRT, the risk of death within 90 days for peripheral non-small cell lung cancer is extremely low. ${ }^{3}$

Avoiding surgical morbidity by using radiotherapy is a well-established strategy and has for a long time been the standard of care in other settings. In laryngeal cancer, radiotherapy is used even though local recurrence is six times higher $(12 \%$ vs $2 \%)$ than with laryngectomy, because salvage laryngectomy ensures that diseasefree survival is not affected and voice preservation can be achieved $64 \%$ of the time. ${ }^{4}$ Similarly, local recurrence in breast cancer is more than 4 times higher ( $9 \%$ vs $2 \%$ ) with lumpectomy and radiotherapy versus mastectomy; however, salvage mastectomy ensures that survival is not compromised.

Prospective clinical trials to determine how best to detect local recurrence after SBRT and to evaluate operative mortality with salvage surgery should be the focus of research in the absence of randomized comparative trials.

Sashendra Senthi, FRANZCR The William Buckland Radiotherapy Centre

Melbourne, Australia

\section{References}

1. Crabtree TD, Puri V, Robinson C, Bradley J, Broderick S, Patterson GA, et al. Analysis of first recurrence and survival in patients with stage I nonsmall cell lung cancer treated with surgical resection or stereotactic radiation therapy. J Thorac Cardiovasc Surg. 2014;147:1183-91; discussion 1191-2.

2. American Association for Thoracic Surgery. Major lung resection safer than ever, especially at the busiest hospitals. Available at: http://aats.org/multimedia/ files/PressReleases/AATS2014-Pezzi-PR-Lung-Can cer-Surgery-Mortality.pdf. Accessed May 5, 2014.

3. Senthi S, Senan S. Surgery for early-stage lung cancer: post-operative 30-day versus 90-day mortality and patient-centred care [letter]. Eur J Cancer. 2014:50:675-7.

4. Induction chemotherapy plus radiation compared with surgery plus radiation in patients with advanced laryngeal cancer. The Department of Veterans Affairs Laryngeal Cancer Study Group. N Engl J Med. 1991:324:1685-90.

5. Veronesi U, Cascinelli N, Mariani L, Greco M, Saccozzi R, Luini A, et al. Twenty-year follow-up of a randomized study comparing breast-conserving surgery with radical mastectomy for early breast cancer. N Engl J Med. 2002;347:1227-32.

http://dx.doi.org/10.1016/ j.jtcvs.2014.05.010 